\title{
Changes in soil organic carbon and nitrogen after 26 years of farmland management on the Loess Plateau of China
}

\author{
ZHOU Zhengchao ${ }^{1 *}$, ZHANG Xiaoyan ${ }^{1}$, GAN Zhuoting ${ }^{2}$ \\ ${ }^{1}$ Department of Tourism and Environmental Sciences, Shaanxi Normal University, Xi'an 710062, China; \\ ${ }^{2}$ Key Laboratory of Disaster Survey and Mechanism Simulation of Shaanxi Province, Baoji University of Arts and Sciences, \\ Baoji 721007, China
}

\begin{abstract}
Soil carbon $(\mathrm{C})$ and nitrogen $(\mathrm{N})$ play a crucial role in determining the soil and environmental quality. In this study, we investigated the effects of 26 years (from 1984 to 2010) of farmland management on soil organic carbon (SOC) and soil $\mathrm{N}$ in abandoned, wheat (Triticum aestivum L.) non-fertilized, wheat fertilized (mineral fertilizer and organic manure) and alfalfa (Medicago Sativa L.) non-fertilized treatments in a semi-arid region of the Loess Plateau, China. Our results showed that SOC and soil total N contents in the 0-20 cm soil layer increased by $4.29(24.4 \%)$ and $1.39 \mathrm{Mg} / \mathrm{hm}^{2}$ (100\%), respectively, after the conversion of farmland to alfalfa land. Compared to the wheat non-fertilized treatment, SOC and soil total $\mathrm{N}$ contents in the $0-20 \mathrm{~cm}$ soil layer increased by 4.64 (26.4\%) and $1.18 \mathrm{Mg} / \mathrm{hm}^{2}$ (85.5\%), respectively, in the wheat fertilized treatment. In addition, we found that the extents of changes in SOC, soil total $\mathrm{N}$ and mineral $\mathrm{N}$ depended on soil depth were greater in the upper soil layer $(0-30 \mathrm{~cm})$ than in the deeper soil layer $(30-100 \mathrm{~cm})$ in the alfalfa land or fertilizer-applied wheat land. Fertilizer applied to winter wheat could increase the accumulation rates of SOC and soil total N. SOC concentration had a significant positive correlation with soil total $\mathrm{N}$ concentration. Therefore, this study suggested that farmland management, e.g. the conversion of farmland to alfalfa forage land and fertilizer application, could promote the sequestrations of $\mathrm{C}$ and $\mathrm{N}$ in soils in semi-arid regions.
\end{abstract}

Keywords: soil organic carbon (SOC); soil N; fertilizer; land use change; semi-arid area

Citation: ZHOU Zhengchao, ZHANG Xiaoyan, GAN Zhuoting. 2015. Changes in soil organic carbon and nitrogen after 26 years of farmland management on the Loess Plateau of China. Journal of Arid Land, 7(6): 806-813. doi: 10.1007/s40333-015-0051-y

Soil organic carbon (SOC) stock is an important indicator of the long-term sustainability of agricultural production systems. Many attributes of soil characteristics (e.g. soil structure and physical fertility, microbial activity, nutrient availability and cycling) that affect agricultural productivity and ecosystem function are influenced by the SOC status (Lal, 2002). In addition, changes in soil carbon (C) have implications for soil $\mathrm{C}$ stocks and the ability to sequester $\mathrm{C}$ or mitigate $\mathrm{CO}_{2}$ emissions in terrestrial ecosystems (Krogh et al., 2003; Wang et al., 2008; Wiesmeier et al., 2012; Kumar et al., 2013; Deng et al., 2014a; Song et al., 2014; Yang et al., 2014). Soil C is also often associ- ated with other major nutrients, especially nitrogen $(\mathrm{N})$, and hence influences the cycling and availability of nutrients for crop and pasture production. Therefore, enhancing SOC sequestration in terrestrial ecosystems is an important strategy for improving soil quality and controlling the rise in the concentration of atmospheric $\mathrm{CO}_{2}$ (Lal, 2002; Mclauchlan et al., 2006).

Various studies from around the world have shown that land use or management practices play important roles in maintaining or building soil C (Mensah et al., 2003; Mclauchlan et al., 2006; Wang et al., 2008; Song et al., 2014). It is well documented that the conversion of farmland to grassland will significantly

*Corresponding author: ZHOU Zhengchao (E-mail: zczhou@snnu.edu.cn) Received 2015-01-15; revised 2015-03-29; accepted 2015-04-13

(C) Xinjiang Institute of Ecology and Geography, Chinese Academy of Sciences, Science Press and Springer-Verlag Berlin Heidelberg 2015 
increase soil C sequestration (Mensah et al., 2003; Chang et al., 2011; Deng et al., 2014a). In addition, Wang et al. (2009) reported that the conversion of grassland to cropland resulted in a loss of SOC. From the above, we can see that the conversion of farmland to grassland is a good way to increase soil $\mathrm{C}$ sequestration. However, as food demand increases, especially in developing countries that have over $850 \times 10^{6}$ food-insecure people (Borlaug, 2007), little cropland can be converted to grassland. Therefore, understanding the long-term effects of farmland cultivation practices on soil $\mathrm{C}$ is also as important as the conversion of farmland to grassland in the future management of soil C storage. Johnson et al. (2007) reported that organic production can also increase SOC compared to the conventional production systems. A number of practices associated with organic management of farmland (e.g. surface mulching, manure application, fallow length reducing, cover cropping, green manuring and crop rotation) are likely to increase soil C sequestration (Manna et al., 2005; Mulumba and Lal, 2008; Thorburn et al., 2012; Deng et al., 2014b). However, there were few studies on the long-term effects of farmland cultivation vs. the conversion of farmland to grassland on soil $\mathrm{C}$ sequestration.

Most previous studies on the effect of land use or management practices on SOC were focused on the surface soil layers $(0-30 \mathrm{~cm})$, and relatively little is known about soil $\mathrm{C}$ or nutrient stocks throughout the soil profile (Thorburn et al., 2012; Dai et al., 2014; Deng et al., 2014b). The lack of consideration for soil $\mathrm{C}$ changes in the deeper soil layers may be problematic (Baker et al., 2007). The consideration of soil C in the deeper soil layers is important when comparing annual crops to perennial grass, such as wheat vs. alfalfa, because of the greater allocation of roots in the deeper soil layers in perennial grass, especially in arid and semi-arid regions.

Therefore, understanding the long-term effects of the conversion of farmland to perennial grass forage land and the farmland cultivation on soil $\mathrm{C}$ in the whole soil profile is necessary for the sustainability of the field ecosystems. In this study, we conducted a field experiment to examine the differences in soil $\mathrm{C}$ throughout the whole soil profile $(0-100 \mathrm{~cm})$ after a long-term (26 years) farmland management in a semi-arid area of the Chinese Loess Plateau. The objectives of this study were to: (1) estimate the distribution of SOC in the $0-100 \mathrm{~cm}$ soil profile under four different farmland management practices (i.e. abandoned, planting alfalfa, planting winter wheat with and without fertilizer); (2) estimate the long-term effect of the conversion of farmland (winter wheat land) to alfalfa forage land on SOC sequestration; and (3) estimate the long-term effect of fertilizer application on SOC sequestration.

\section{Materials and methods}

\subsection{Study area}

The field study site was set up in 1984 at the Changwu Agro-ecological Experimental Station on the Loess Plateau, Chinese Academy of Sciences, located in Changwu county, Shaanxi province, China (107 $40^{\prime} \mathrm{E}$, $35^{\circ} 12^{\prime} \mathrm{N} ; 1,220 \mathrm{~m}$ asl). This area is characterized by a semi-arid climate with a warm summer and a very cold winter. The annual mean temperature is $9.1^{\circ} \mathrm{C}$ and the annual mean open pan evaporation is $1,440 \mathrm{~mm}$. The 50-year mean annual precipitation is $580 \mathrm{~mm}$, with $70 \%$ of it occurring during June to September. The SOC concentration, SOC content, soil total $\mathrm{N}$ concentration, soil total $\mathrm{N}$ content and bulk density in the upper soil layer of $0-20 \mathrm{~cm}$ measured in April 1984 (at the start of the experiment) were $6.5 \mathrm{~g} / \mathrm{kg}$, $16.9 \mathrm{Mg} / \mathrm{hm}^{2}, 0.62 \mathrm{~g} / \mathrm{kg}, 1.61 \mathrm{Mg} / \mathrm{hm}^{2}$ and $1.30 \mathrm{~g} / \mathrm{cm}^{3}$, respectively (Huang et al., 2003).

\subsection{Experimental design and treatments}

The experiment began in 1984 on land that had previously been cultivated with continuous winter wheat (Triticum aestivum L.) for at least 30 years. The plot size was $10.3 \mathrm{~m} \times 6.5 \mathrm{~m}$ and every two plots were separated by a $0.5-\mathrm{m}$ strip. All the plots were managed in the same way each year by the workers of the Changwu Agro-ecological Experimental Station on the Loess Plateau from 1984 to 2010. The treatments selected for this study were: (1) abandoned (control plots with no cropping); (2) wheat non-fertilized (continuous non-fertilized wheat-wheat cultivation); (3) alfalfa non-fertilized (continuous non-fertilized alfalfa-alfalfa cultivation); and (4) wheat fertilized (continuous wheat-wheat cultivation with mineral $\mathrm{N}$ and $\mathrm{P}$ fertilizer plus farmyard manure). There were three 
plots for each treatment. These plots were considered to be true replicates. In this study, mineral $\mathrm{N}$ fertilizer was applied as urea and mineral $\mathrm{P}$ fertilizer was applied as superphosphate. The manure (M) was mainly cow excretion, containing $10.7 \mathrm{~g} \mathrm{C} / \mathrm{kg}$ and $1.16 \mathrm{~g} \mathrm{~N} / \mathrm{kg}$ (equivalent to $87 \mathrm{~kg} \mathrm{~N} /\left(\mathrm{hm}^{2}\right.$.a) at the application rate used). Details of the fertilizer applications can be seen in Huang et al. (2003). Wheat was sown in September and harvested manually in June next year. Fertilizer was applied at a single dose 5-7 days prior to wheat sowing each year. Alfalfa harvesting has lasted for 26 years since being sowed in April 1984. Alfalfa was also harvested manually, cutting close to the ground, and all the harvested biomass was removed from the plots in June and September each year. All wheat and alfalfa biomass was measured after air-drying. A fuller description of the experimental station and experimental design was given in Huang et al. (2003).

\subsection{Soil sampling and laboratory analysis}

Soil samples were taken at three points in each plot. Litter horizons were removed before soil sampling. At each point, soil samples was done in 15 soil layers (5-cm sections from 0 to $50 \mathrm{~cm}$ depth and $10-\mathrm{cm}$ sections from 50 to $100 \mathrm{~cm}$ depth) using a soil drilling sampler (6-cm inner diameter) in June 2010. We then mixed the same soil layer together to make one sample in each plot. Thus, there were three replicate soil samples for each treatment in the same layer. All samples were sieved through a 2-mm screen, and roots and other debris were removed. Each sample was air-dried and stored at room temperature for the determination of soil physical-chemical properties. The soil bulk density of the $0-20 \mathrm{~cm}$ layers in each plot was measured using a soil bulk sampler with a 5-cm-diameter and 5-cm-high stainless steel cutting ring (5 replicates) at points adjacent to the soil sampling site. The original volume of each soil core and its dry mass after oven-drying at $105^{\circ} \mathrm{C}$ were measured.

Soil water content was measured gravimetrically and expressed as a percentage of soil water to dry soil weight. Soil bulk density $\left(\rho ; \mathrm{g} / \mathrm{cm}^{3}\right)$ was calculated using the inner diameter of the core sampler, sampling depth and the oven dry weight of the composite soil samples. Soil organic carbon (SOC) was determined by $\mathrm{K}_{2} \mathrm{Cr}_{2} \mathrm{O}_{7}-\mathrm{H}_{2} \mathrm{SO}_{4}$ oxidation (Nelson and Sommers,
1996). Soil total $N$ was measured using the Kjeldahl method (Bremner, 1996). Soil ammonium and nitrate were extracted by vigorously shaking the sample with $50 \mathrm{~mL}$ of $2.0 \mathrm{~mol} / \mathrm{L} \mathrm{KCl}$ for $30 \mathrm{~min}$, filtering the extract and measuring $\mathrm{NH}_{4}{ }^{+}$nitrogen and $\mathrm{NO}_{3}{ }^{-}$nitrogen concentrations using a continuous flow spectrophotometer (Skalar 5100, Breda, The Netherlands) by following cadmium reduction (at $\lambda=540 \mathrm{~nm}$ ) for nitrate and cation complexation (at $\lambda=660 \mathrm{~nm}$ ) for ammonium.

\subsection{Calculations and data analysis}

SOC and total $\mathrm{N}$ stocks were calculated using the following equation:

$$
S=(E C \times \rho \times h) / 10 .
$$

Where, $S$ is the element stock $\left(\mathrm{Mg} / \mathrm{hm}^{2}\right)$; $E C$ is the element concentration $(\mathrm{g} / \mathrm{kg}) ; \rho$ is the bulk density $\left(\mathrm{g} / \mathrm{cm}^{3}\right)$; and $h$ is the thickness of the soil layer $(\mathrm{cm})$.

The values of SOC and soil total $\mathrm{N}$ stocks for the $0-5,5-10,10-15$ and 15-20 cm layers were summed to calculate SOC and soil total $\mathrm{N}$ stocks in the top soil layer of $0-20 \mathrm{~cm}$.

ANOVA analyses were carried out with SPSS 17.0 statistical software package (SPSS Inc., Chicago, IL, USA) to test the effects of different treatments on soil bulk density, SOC, soil total $\mathrm{N}$ and mineral $\mathrm{N}$.

\section{Results}

\subsection{SOC concentrations in the soil profile}

For each of the four treatments, SOC concentrations were highest in the $0-5 \mathrm{~cm}$ soil layer, declined with soil depths down to the $45-50 \mathrm{~cm}$, and then slightly increased with depths from 50 to $100 \mathrm{~cm}$ (Fig. 1a). SOC concentrations also showed a greater difference in the upper soil layer $(0-30 \mathrm{~cm})$ and little difference in the deeper soil layer $(30-100 \mathrm{~cm})$ among different treatments (Fig. 1a). The lowest and highest SOC concentrations in the $0-30 \mathrm{~cm}$ soil layers were found in the abandoned and wheat fertilized treatments, respectively. These results indicated that cultivation could increase SOC concentrations in the upper soil layers. In addition, different cultivation and management strategies could also result in different SOC concentrations in the upper soil layers. Compared to the wheat fertilized treatment and alfalfa non-fertilized treatment, SOC concentrations in the wheat non-fertilized treatment were significantly lower in the upper soil layers. 

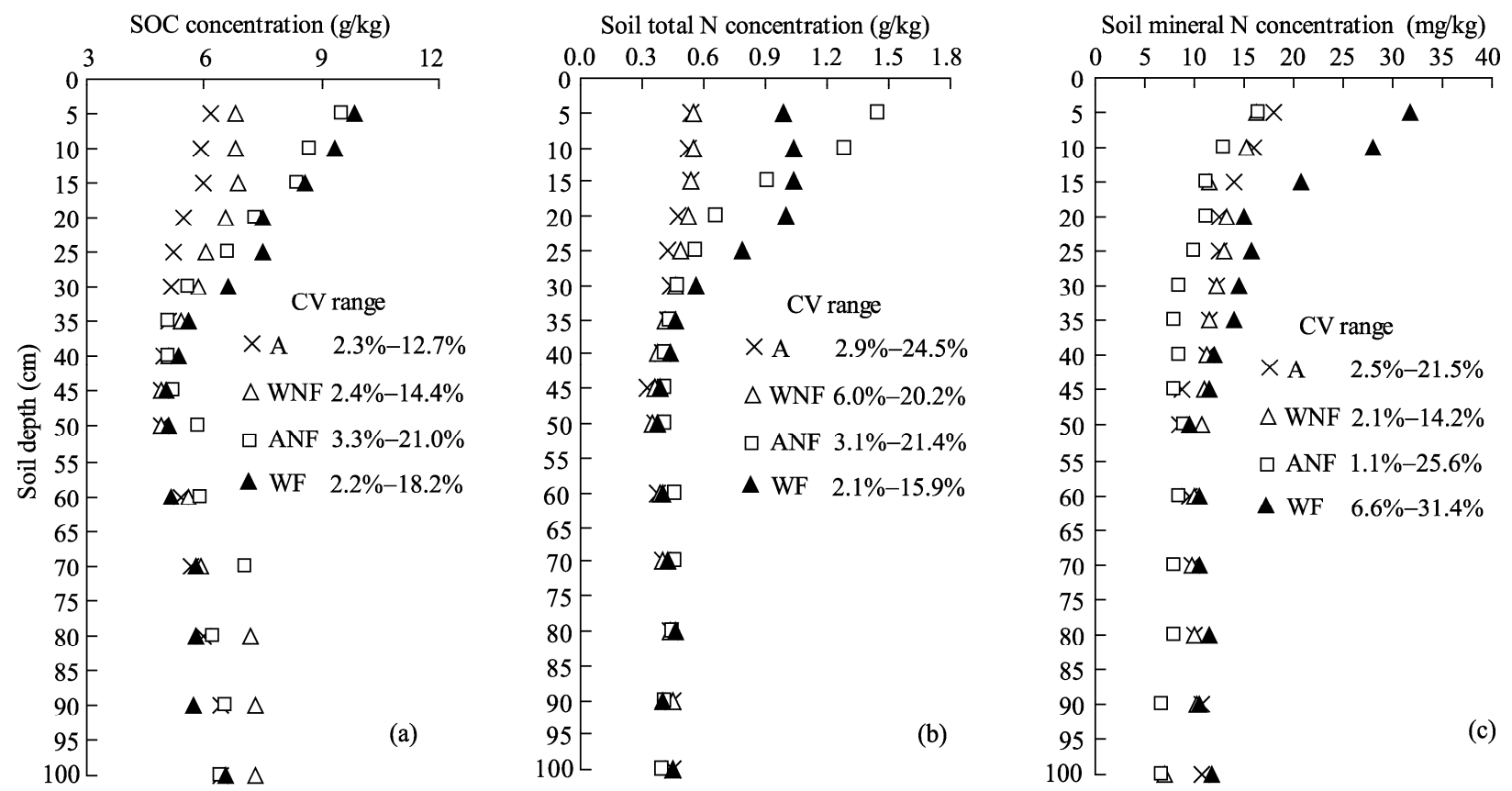

Fig. 1 Average values of (a) SOC (soil organic carbon), (b) soil total N (nitrogen) and (c) soil mineral N concentrations in the soil depths of 0-100 cm after 26 years of farmland management. Management treatments are abandoned (A), wheat non-fertilized (WNF), alfalfa non-fertilized (ANF) and wheat fertilized (WF). CV is the coefficient of variation.

This suggested that farmland management, e.g. fertilizer application and the conversion of farmland to alfalfa forage land, could increase the SOC concentrations.

\subsection{Soil total $\mathrm{N}$ concentrations in the soil profile}

For each treatment, soil total $\mathrm{N}$ concentrations were highest in the $0-5 \mathrm{~cm}$ soil layer, decreased with soil depths down to the 35-40 cm, and then remained constant in the soil layers of $40-100 \mathrm{~cm}$ (Fig. 1b). The concentrations of soil total $\mathrm{N}$ in the abandoned and wheat non-fertilized treatments were not significantly different, and were significantly lower than those in the other two treatments (wheat fertilized and alfalfa non-fertilized) in the $0-25 \mathrm{~cm}$ soil layers (Fig. 1b). There were no significant differences in the total $\mathrm{N}$ concentrations in the $30-100 \mathrm{~cm}$ soil layers among the four treatments.

\subsection{Soil mineral $\mathbf{N}$ concentrations in the soil profile}

For each of the four treatments, soil mineral $\mathrm{N}$ concentrations were highest in the $0-5 \mathrm{~cm}$ soil layer, decreased with soil depths down to the $35-40 \mathrm{~cm}$, and then slightly changed with depths from 40 to $100 \mathrm{~cm}$ (Fig. 1c). There were no significant differences ob- served in the soil mineral $\mathrm{N}$ concentrations in the same soil layer among the abandoned, wheat non-fertilized and alfalfa non-fertilized treatments. However, soil mineral $\mathrm{N}$ concentrations in the upper soil layers (0-15 $\mathrm{cm})$ under the wheat fertilized treatment were significantly higher than those under the other three treatments (abandoned, wheat non-fertilized and alfalfa non-fertilized), and this significant difference disappeared in the soil layers of 15-100 cm (Fig. 1c).

\subsection{Relationship between SOC and soil N}

SOC concentration had a significant positive correlation with soil total $\mathrm{N}$ concentration (Fig. 2) and soil mineral $\mathrm{N}$ concentration (Fig. 3). The slopes of the relationship between SOC and soil total $\mathrm{N}$ concentrations in the abandoned and wheat non-fertilized treatments (6.1739 and 8.1096, respectively) were higher than those in the wheat fertilized and alfalfa non-fertilized treatments (4.5807 and 3.2674, respectively; Fig. 2b). This result indicated that, for the abandoned and wheat non-fertilized treatments, smaller changes of soil total $\mathrm{N}$ concentrations would result in larger changes of SOC concentrations at the lower soil total $\mathrm{N}$ concentration levels. However, this 

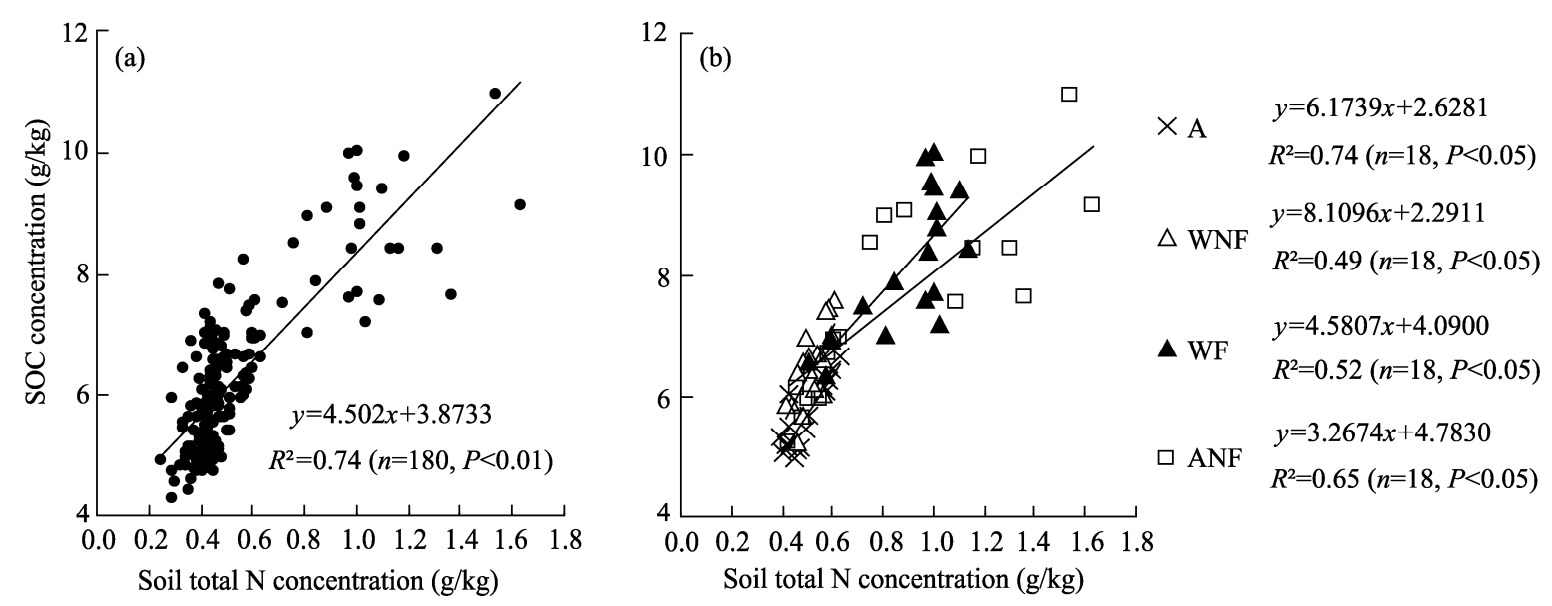

Fig. 2 Relationship between SOC and soil total $\mathrm{N}$ concentrations in the whole soil profile among the four treatments (a) and in the $0-30$ $\mathrm{cm}$ soil layer in each treatment (b)
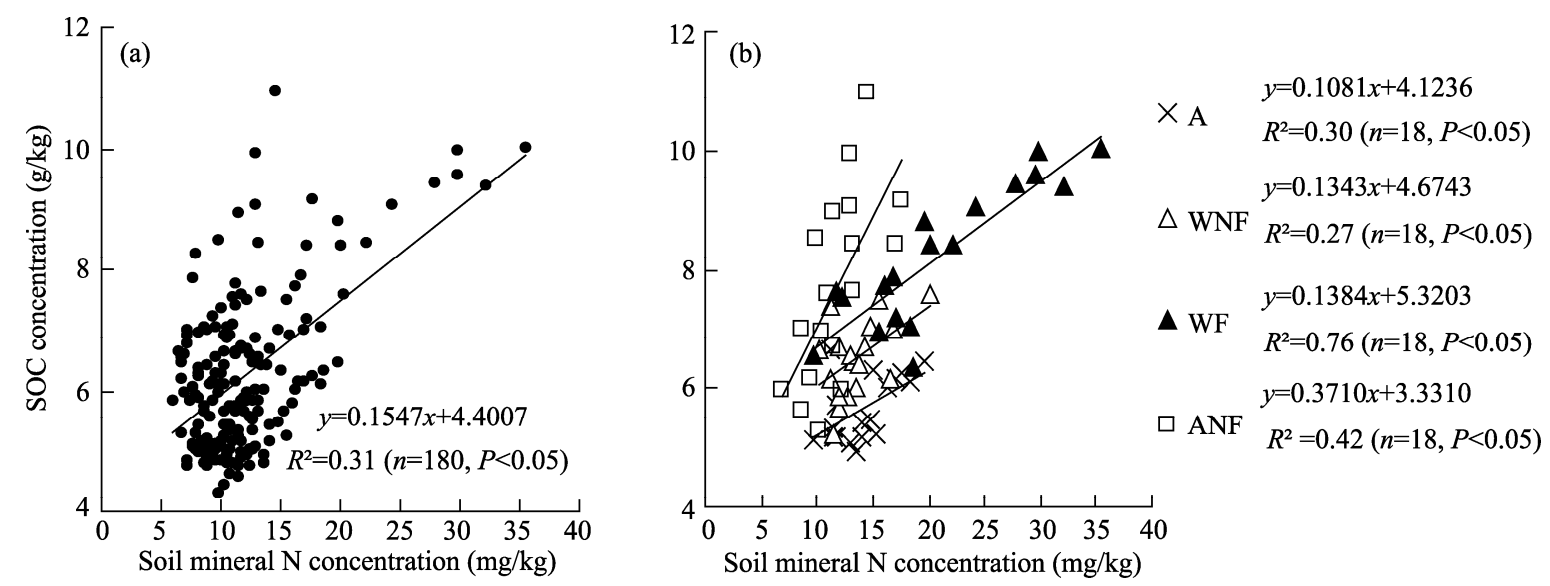

Fig. 3 Relationship between SOC and soil mineral $\mathrm{N}$ concentrations in the whole soil profile among the four treatments (a) and in the $0-30 \mathrm{~cm}$ soil layer in each treatment (b)

phenomenon was not found in the relationship between SOC and soil mineral N concentrations (Fig. 3b).

\section{Discussion}

\subsection{Effect of the conversion of farmland to alfalfa forage land on SOC and soil total N}

Significant differences in SOC contents among different treatments indicated that SOC can be increased by the conversion of planting winter wheat to alfalfa. The results showed that SOC content in the surface soil layer $(0-20 \mathrm{~cm})$ in alfalfa land was $24.4 \%$ greater than that in wheat-wheat rotation land (Table 1). This suggested a considerable accumulation of organic $\mathrm{C}$ in soils following the conversion of farmland to alfalfa forage land. This result is consistent with the findings in other areas and ecosystems. For example, Deng et al. (2014b) reported that soil C always increased in the top soil layer with the number of planting years increased. Su (2007) reported that SOC increased by $35 \%$ (0-5 cm soil layer) following the conversion of cropland to alfalfa land for 4 years in an area of Northwest China near the present study area. Mensah et al. (2003) found that soil C increased by $52.7 \%$ following the conversion of farmland to grassland for 5-12 years in east-central Saskatchewan, Canada. Malhi et al. (2003) observed a 114\% increase in soil C (0-5 cm soil layer) in a 30-year-old alfalfa field compared to an adjacent cultivated field in Canada.

Our results also showed that total $\mathrm{N}$ content in the soil increased by $1.39 \mathrm{Mg} / \mathrm{hm}^{2}$ in the top soil layer of $0-20 \mathrm{~cm}$ after the conversion of wheat land to alfalfa 
Table 1 Soil bulk density, SOC and soil total N in the 0-20 cm soil depth under different treatments in 2010

\begin{tabular}{|c|c|c|c|c|c|c|}
\hline Treatment & $\begin{array}{l}\text { Soil bulk density } \\
\qquad\left(\mathrm{g} / \mathrm{cm}^{3}\right)\end{array}$ & $\begin{array}{c}\text { SOC } \\
\text { concentration }(\mathrm{g} / \mathrm{kg})\end{array}$ & $\begin{array}{l}\text { SOC content } \\
\left(\mathrm{Mg} / \mathrm{hm}^{2}\right)\end{array}$ & $\begin{array}{l}\text { Annual accumulation rate } \\
\text { of SOC }\left(\mathrm{Mg} \mathrm{C} /\left(\mathrm{hm}^{2} \cdot \mathrm{a}\right)\right)\end{array}$ & $\begin{array}{c}\text { Soil total N } \\
\text { concentration }(\mathrm{g} / \mathrm{kg})\end{array}$ & $\begin{array}{c}\text { Soil total N } \\
\text { content }\left(\mathrm{Mg} / \mathrm{hm}^{2}\right)\end{array}$ \\
\hline A & $1.34 \pm 0.03^{\mathrm{a}}$ & $5.89 \pm 0.53^{b}$ & $15.79 \pm 1.08^{b}$ & -0.043 & $0.52 \pm 0.077^{\mathrm{b}}$ & $1.39 \pm 0.19^{\mathrm{b}}$ \\
\hline WNF & $1.28 \pm 0.04^{\mathrm{b}}$ & $6.86 \pm 0.25^{b}$ & $17.56 \pm 1.10^{\mathrm{b}}$ & 0.025 & $0.54 \pm 0.011^{\mathrm{b}}$ & $1.38 \pm 0.10^{\mathrm{b}}$ \\
\hline ANF & $1.29 \pm 0.04^{\mathrm{b}}$ & $8.47 \pm 1.34^{\mathrm{a}}$ & $21.85 \pm 2.14^{\mathrm{a}}$ & 0.190 & $1.074 \pm 0.351^{\mathrm{a}}$ & $2.78 \pm 0.58^{\mathrm{a}}$ \\
\hline WF & $1.26 \pm 0.05^{\mathrm{b}}$ & $8.81 \pm 1.01^{\mathrm{a}}$ & $22.20 \pm 1.87^{\mathrm{a}}$ & 0.200 & $1.015 \pm 0.028^{\mathrm{a}}$ & $2.56 \pm 0.16^{\mathrm{a}}$ \\
\hline
\end{tabular}

Note: SOC, soil organic carbon; N, nitrogen. A, abandoned; WNF, wheat non-fertilized; ANF, alfalfa non-fertilized; WF, wheat fertilized. Different lowercase letters indicate significant differences at $P<0.05$ level among different treatments.

land for 26 years (Table 1). This result agrees with the finding of previous research (Su, 2007). Su (2007) reported that soil total $\mathrm{N}$ content in the top soil layer of $0-5 \mathrm{~cm}$ was significantly increased following the conversion of cropland to alfalfa forage land within a relatively short time period (4 years).

\subsection{Effect of fertilizer application on SOC and soil total $\mathbf{N}$}

Application of fertilizer in wheat farmland over 26 years resulted in the increases of SOC and soil total $\mathrm{N}$ contents (4.64 and $1.18 \mathrm{Mg} / \mathrm{hm}^{2}$, respectively; Table $1)$. The result is in agreement with the finding of Glendining and Powlson (1995) that SOC and total N contents in arable soils can be increased by adding $\mathrm{N}$ fertilizer.

In this study, the accumulation rates of SOC were 0.025 and $0.200 \mathrm{Mg} \mathrm{C} /\left(\mathrm{hm}^{2} \cdot \mathrm{a}\right)$ in the non-fertilized wheat and fertilized wheat treatments, respectively, after 26 years of continuous cropping (Table 1). The result showed that fertilizer application could accelerate the accumulation of SOC. However, these values were lower than those reported previously. Jenkinson et al. (1992) reported that the rate of increase in the SOC content was $1.7 \mathrm{Mg} \mathrm{C} /\left(\mathrm{hm}^{2} \cdot \mathrm{a}\right)$ for an experimental plot treated with $144 \mathrm{~kg} \mathrm{~N} /\left(\mathrm{hm}^{2} \cdot\right.$ a) at Rothamsted of UK. One explanation for the difference of the increase rate was that the annual precipitation $(580 \mathrm{~mm})$ was lower and the annual evaporation was higher $(1,440 \mathrm{~mm})$ in our study area than those $(710$ and $599 \mathrm{~mm}$, respectively) in Rothamsted of UK, indicating that the loess soil in our study area was drier, resulting in the lower rates of decomposition. Moreover, the turnover time (26 years) at our study site was approximately $50 \%$ higher than that (approximately 16 years) at Rothamsted of UK. According to the study of Mann (1986), the greatest change rate in SOC content oc- curred in the first 20 years after the land use changed. The longer turnover time in our study may also result in a lower accumulation rate of SOC.

\subsection{Relationship between SOC and soil total N}

In this study, SOC concentration had a significant positive correlation with soil total $\mathrm{N}$ concentration. Piovanelli et al. (2006) found that SOC was highly correlated with soil total $\mathrm{N}$ under different management regimes. In the present study, the dynamics of soil total $\mathrm{N}$ concentrations in each soil layer were consistent with the changes of SOC concentrations among the four treatments. Zhang et al. (2009) reported that the intensive tillage and other practices carried out during the process of land conversion affect not only the SOC but also the soil total N. Alfalfa, which can derive $\mathrm{N}$ accumulation by symbiotic fixation, is expected to have a concomitant positive effect on both $\mathrm{C}$ and $\mathrm{N}$ added to the soil (Wu et al., 2006). Thus, for the alfalfa non-fertilized and wheat fertilized treatments, a higher soil total $\mathrm{N}$ concentration would result in a higher SOC concentration, especially in the upper soil layer of 0-30 cm (Fig. 1a).

\subsection{Distribution of $\mathrm{C}$ and $\mathrm{N}$ in the soil profile}

Due to a lack of data on SOC and soil total N contents below the surface soil layer (namely $20-100 \mathrm{~cm}$ depth) for 1984, the changes of SOC and soil total N contents in subsurface soil layer between 1984 and 2010 could not be calculated. Compared to abandoned treatment, higher SOC concentration values were observed in the other three treatments in the upper soil layer of 0-30 cm (Fig. 1a). However, the differences in the SOC concentrations were not obvious in the deeper soil layer $(30-100 \mathrm{~cm})$ in 2010. The difference of SOC concentration between the upper and deeper soil layers can be explained by the root-decay process. Most plant 
roots are located in the surface soil layer and constitute a main source of surface soil C (Zhou and Shangguan, 2007). Thus, $C$ is released near the surface soil layer when the roots die, resulting in the increase of SOC in the surface soil layer.

Just like SOC, soil $\mathrm{N}$ concentration (total $\mathrm{N}$ and mineral $\mathrm{N})$ in the upper soil layer $(0-30 \mathrm{~cm}$ depth) was greater than that in the deeper soil layer (Figs. 1b and c). Soil $\mathrm{N}$ is usually transferred via roots from the subsurface to the surface soil layers during plant growth and is released near the surface soil layer when the roots die, resulting in the increase of soil $\mathrm{N}$ concentration in the surface soil layer (in this study, the abandoned land was also cultivated with winter wheat at least 30 years before 1984). Meanwhile, a higher soil total $\mathrm{N}$ concentration was observed in alfalfa plots in the $0-10 \mathrm{~cm}$ soil layer, indicating that planting alfalfa is pretty effective for $\mathrm{N}$ fixation.

\section{Conclusions}

In summary, SOC and soil total $\mathrm{N}$ were strongly influenced by farmland management. The conversion of farmland under a wheat-wheat rotation to permanent alfalfa forage land could increase both SOC and soil total $\mathrm{N}$ concentrations in the soil depth of $0-30 \mathrm{~cm}$ over a 26-year period in a semi-arid area of the Loess Plateau. Fertilizer applied to winter wheat could increase the accumulation rates of SOC and soil total N. SOC concentration had a significant positive correlation with soil total $\mathrm{N}$ concentration. Therefore, planting alfalfa and applying fertilizer can both result in the increase of soil C storage in the semi-arid regions.

\section{Acknowledgements}

This study was funded by the Fok Ying-Tong Education Foundation for Young Teachers in the Higher Education Institutions of China (131025) and the Natural Science Foundation of Shaanxi Province (2014KJXX-52).

\section{References}

Baker J M, Ochsner T E, Venterea R T, et al. 2007. Tillage and soil carbon sequestration-what do we really know? Agriculture, Ecosystems \& Environment, 118(1-4): 1-5.

Borlaug N. 2007. Feeding a hungry world. Science, 318: 359.

Bremner J M. 1996. Nitrogen-total. In: Sparks L, Page A L, Helmke P A, et al. Methods of Soil Analysis. Part 3: Chemical Methods. Madison:
Soil Science Society of America Inc., 1085-1121.

Chang R Y, Fu B J, Liu G H, et al. 2011. Soil carbon sequestration potential for “Grain for Green” project in Loess Plateau, China. Environmental Management, 48: 1158-1172.

Dai E F, Zhai R X, Ge Q S, et al. 2014. Detecting the storage and change on topsoil organic carbon in grasslands of Inner Mongolia from 1980s to 2010s. Journal of Geographical Sciences, 24(6): 1035-1046.

Deng L, Shangguan Z P, Sweeney S. 2014a. “Grain for Green” driven land use change and carbon sequestration on the Loess Plateau, China. Scientific Reports, 4: 7039, doi: 10.1038/srep07039.

Deng L, Wang K B, Li J P, et al. 2014b. Carbon storage dynamics in alfalfa (Medicago sativa) fields on the Loess Plateau, China. CLEAN-Soil, Air, Water, 42: 1253-1262.

Glendining M J, Powlson D S. 1995. The effects of long continued applications of inorganic nitrogen fertilizer on soil organic nitrogen-a review. In: Lal R, Stewart B A. Soil Management: Experimental Basis for Sustainability and Environmental Quality, Advances in Soil Science. Boca Raton: Lewis Publishers, 385-446.

Huang M B, Dang T H, Gallichand J, et al. 2003. Effect of increased fertilizer applications to the wheat crop on soil-water depletion in the Loess Plateau, China. Agricultural Water Management, 58: 267-278.

Jenkinson D S, Harkness D D, Vance E D, et al. 1992. Calculating net primary production and annual input of organic matter to soil from radiocarbon measurements. Soil Biology and Biochemistry, 24: 295-308.

Johnson J M F, Franzluebbers A J, Weyers S L, et al. 2007. Agricultural opportunities to mitigate greenhouse gas emissions. Environmental Pollution, 150: 107-124.

Krogh L, Noergaard A, Hermansen M, et al. 2003. Preliminary estimates of contemporary soil organic carbon stocks in Denmark using multiple datasets and four scaling-up methods. Agriculture, Ecosystem \& Environment, 96: 19-28.

Lal R. 2002. Soil carbon dynamics in cropland and rangeland. Environmental Pollution, 116: 353-362.

Malhi S S, Brandt S, Gill K S. 2003. Cultivation and grassland type effects on light fraction and total organic $\mathrm{C}$ and $\mathrm{N}$ in a Dark Brown Chernozemic soil. Canadian Journal of Soil Science, 83: 145-153.

Mann L K. 1986. Changes in soil carbon storage after cultivation. Soil Science, 142: 279-288.

Manna M C, Swarup A, Wanjari R H, et al. 2005. Long-term effect of fertilizer and manure application on soil organic carbon storage, soil quality and yield sustainability under sub-humid and semi-arid tropical India. Field Crops Research, 93(2): 264-280.

Mclauchlan K K, Hobbie S E, Post W M. 2006. Conversion from agriculture to grassland builds soil organic matter on decadal timescales. Ecological Applications, 16(1): 143-153.

Mensah F, Schoenau J J, Malhi S S. 2003. Soil carbon changes in cultivated and excavated land converted to grasses in east-central Saskatchewan. Biogeochemistry, 63: 85-92.

Mulumba L N, Lal R. 2008. Mulching effects on selected soil physical properties. Soil and Tillage Research, 98: 106-111.

Nelson D W, Sommers L E. 1996. Total carbon, organic carbon, and organic matter. In: Sparks D L, Page A L, Helmke P A. Methods of 
Soil Analysis. Part 3: Chemical Methods. Madison: Soil Science Society of America Inc., 539-579.

Piovanelli C, Gamba C, Brandi G, et al. 2006. Tillage choices affect biochemical properties in the soil profile. Soil and Tillage Research, 90: 84-92.

Kumar S, Lal R, Liu D S, et al. 2013. Estimating the spatial distribution of organic carbon density for the soils of Ohio, USA. Journal of Geographical Sciences, 23(2): 280-296.

Song X H, Peng C H, Zhou G M, et al. 2014. Chinese Grain for Green Program led to highly increased soil organic carbon levels: A meta-analysis. Scientific Reports, 4, 4460, doi:10.1038/srep04460.

Su Y Z. 2007. Soil carbon and nitrogen sequestration following the conversion of cropland to alfalfa forage land in northwest China. Soil and Tillage Research, 92: 181-189.

Thorburn P J, Meier E A, Collins K, et al. 2012. Changes in soil carbon sequestration, fractionation and soil fertility in response to sugarcane residue retention are site-specific. Soil and Tillage Research, 120: 99-111.

Wang Q, Zhang L, Li L, et al. 2009. Changes in carbon and nitrogen of Chernozem soil along a cultivation chronosequence in a semi-arid grassland. European Journal of Soil Science, 60: 916-923.

Wang Z P, Han X G, Li L H. 2008. Effects of grassland conversion to croplands on soil organic carbon in the temperate Inner Mongolia. Journal of Environmental Management, 86: 529-534.

Wiesmeier M, Steffens M, Mueller C M, et al. 2012. Aggregate stability and physical protection of soil organic carbon in semi-arid steppe soils. European Journal of Soil Science, 63: 22-31.

Wu T Y, Schoenau J J, Li F M, et al. 2006. Influence of tillage and rotation systems on distribution of organic carbon associated with particle-size fractions in Chernozemic soils of Saskatchewan, Canada. Biology and Fertility of Soils, 42: 338-344.

Yang R, Su Y Z, Wang M, et al. 2014. Spatial pattern of soil organic carbon in desert grasslands of the diluvial-alluvial plains of northern Qilian Mountains. Journal of Arid Land, 6(2): 136-144.

Zhang T J, Wang Y W, Wang X G, et al. 2009. Organic carbon and nitrogen stocks in reed meadow soils converted to alfalfa fields. Soil and Tillage Research, 105: 143-148.

Zhou Z C, Shangguan Z P. 2007. Vertical distribution of fine roots in relation to soil factors in Pinus tabulaeformis Carr. forests of the Loess Plateau of China. Plant and Soil, 291: 119-129. 